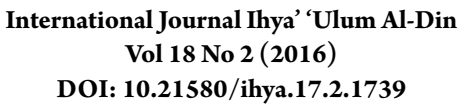

DOI: $10.21580 /$ ihya.17.2.1739

\title{
KELUARGA SAKINAH: Konsep \& Pola Pembinaan
}

\author{
Marmiati Mawardi \\ Balai Litbang Agama Semarang \\ E-mail : atimawardi@gmail.com
}

\begin{abstract}
ABTRACT
This study aims to find out the general description of the sakinah family, the pattern of sakinah family coaching, and the community response to the development of sakinah Family in Salatiga City with the target of community research in Argomulyo District. This research is descriptive with qualitative approach. One of the reseach objects was Uswatun Khasanah from Pamot village, Noborejo Sub-district, originally classified as pre-sakinah. Findings of this study stated that guidance given by KUA (religious officers) in Argomulyo could not reach maximum level because it only served people more with general guidance in the form of religious sermons than in the form of practical skills; while people saw a family could not be justified as ideal unless it meets both spiritual and material needs. Therefore, it is recommended that the Ministry of Religious Affairs revisit its concept of Islamic ideal family, increase the funds for the guidance in order to give better services to more people, and make a good relationship with other elements of regional institutions, religious leaders and public figures.
\end{abstract}

Keywords: Coaching Pattern; Community Response; Sakinah Family

\begin{abstract}
ABSTRAK
Penelitian ini bertujuan untuk mengetahui gambaran umum tentang keluarga sakinah, pola pembinaan keluarga sakinah, dan Respons masyarakat terhadap pembinaan Keluarga sakinah di Kota Salatiga dengan sasaran penelitian masyarakat di Kecamatan Argomulyo. Penelitian ini bersifat diskriptif dengan pendekatan kualitatif. Salah satu kelompok binanan keluarga pra sakinah adalah Uswatun Khasanah, Dusun Pamot, Kelurahan Noborejo, semula tergolong pra sakinah. Pasca Pembinaan ada
\end{abstract}


kesadaran dalam masyarakat untuk mewujudkan kehidupan yang agamis, mengalami peningkatan dibidang keagamaan maupun perekonomian. Perubahan tersebut karena keikutsertaan dalam kegiatan pengajian dan faktor perubahan lingkungan. Keberhasialan ini tidak lepas dari peran penyuluh dan tokoh agama maupun tokoh masyarakat setempat. Pembinaan masih bersifat umum dalam bentuk pengajian, pembinaan ketrampilan belum banyak dilakukan. Pembinaan keluarga sakinah yang dilakukan KUA Argomulyo belum maksimal. Kementrian Agama perlu perlu dipertegas konsep keluarga sakinah disesuaikan dengan kondisi mayarakat dan perlu menambah alokasi dana pembinaan keluaraga agar bisa menjangkau masyarakat luas dan perlu membangan kerjasama dengan Pemda, tokoh agama dan tokoh masyarakat

Kata Kunci : Keluarga Sakinah; Pola Pembinaan; Respons Masyarakat

\section{A. Pendahuluan}

Undang-Undang Nomor 1 tahun 1974 tentang perkawinan, bab II, pasal 1 menyebutkan bahwa perkawinan adalah ikatan lahir batin antara laki-laki dan perempuan yang terbentuk dari perkawinan yang sah sesuai hukum yang berlaku dan bertujuan untuk mewujudkan kehidupan rumah tangga sejahtera yang diliputi rasa kasih sayang atau sakinah, mawaddah dan rahmah. Menurut Ulfatmi (2011, 64-66), sakinah secara harfiah dapat berarti: tenang atau tenteram. Ulfatmi menyimpulkan bahwa keluarga sakinah adalah keluarga yang hidup tenteram dan bahagia, saling mengasihi, saling menghargahi, saling memberi, saling membantu, saling memahami dan berupaya meningkatkan hubungan baik terhadap Tuhan maupun dengan sesama manusia.

Keluarga sakinah adalah keluarga yang dibina atas perkawinan yang sah, mampu memenuhi hajat hidup spiritual dan material secara layak dan seimbang, diliputi suasana kasih sayang antara anggota keluarga dan lingkungannya dengan selaras, serasi serta mampu mengamalkan ,menghayati dan memperdalam nilai-nilai keimanan dan akhlaq yang mulia. (Ditjen Bimas Islam dan penyelenggaraan haji Direktorat Urusan Agama Islam, 2005, 91).

Dewasa ini telah terjadi pergeseran nilai dalam kehidupan keluarga, lembaga perkawinan tidak lagi dipandang sakral disebabkan merosotnya sendi-sendi kehidupan keluarga dan renggangnya hubungan antar anggota keluarga. Badan Penasehatan Pembinaan Dan Pelestarian Perkawinan 
(BP4) bertugas memberi pelayanan konsultasi perkawinan yang telah dibentuk Kementrian Agama tidak banyak berfungsi karena jarang keluarga yang bertikai datang untuk berkonsultasi. Keluarga bermasalah yang datang untuk konsultasi ke BP 4 dalam satu bulan rata-rata ada 5 . Konsultasi ke BP 4 hanya dilakukan Pegawai Negeri, belum merambah kemasyarakat umum. Permasalahan kecil yang muncul dalam kehidupan keluarga mudah sekali menimbulkan percekcokan, sulit didamaikan dan bahkan sampai berakhir dengan perceraian. Di Jawa Tengah pada tahun 2010 terjadi 12.019 kasus cerai, angka ini menduduki rangking tertinggi ke tiga setelah Jawa Barat dan Jawa Timur (Suara Merdeka, 10 Januari 2012. 24).Faktor penyebab perceraian antara lain dipicu masalah ekonomi dan terjadi percekcokan terus menerus. Perceraian juga banyak terjadi karena perkawinan usia dini dan hamil pra nikah.

Heteroginitas masyarakat Salatiga berpengaruh terhadap sudut pandang dalam hal agama. Ada komunitas yang memandang bahwa urusan agama adalah urusan pribadi. Mengaku beragama Islam tetapi tidak menjalankan syariat/ abangan. Perkawinan dari latar belakang perbedaan agama banyak terjadi dan dalam satu keluarga terdapat anggota yang berbeda agama adalah hal yang biasa. Banyak terjadi perkawinan dengan calon pengantin hamil pranikah. Menurut informan kunci yang menangani langsung dalam urusan perkawinan jumlah calon pengantin hamil pra nikah mencapai $50 \%$ dan $75 \%$ rata-rata pasangan calon pengantin sudah pernah melakukan hubungan layaknya suami istri.

Kementrian Agama telah Merancang Program Pembinaan Keluarga Sakinah yang telah diatur dalam Keputusan Menteri Agama RI No. 3 Tahun 1999 tentang Pembinaan gerakan Keluarga Sakinah. Program tersebut ditujukan kepada seluruh keluarga yang berada di Indonesia. Menyikapi kondisi masyarakat sebagaimana tersebut diatas untuk mengetahui bagaimana pelaksanaan Pembinaan Keluarga Sakinah di Kota Salatiga maka perlu dilakukan penelitian.

\section{B. Pembahasan}

\section{Karakteristik Masyarakat}

Wilayah Kota Salatiga terbagi dalam empat kecamatan yaitu Kecamatan Sidorejo,Tingkir, Sidomukti dan Argomulyo. Berdasarkan 
data Kementrian Agama Kota Salatiga tahun 2009, jumlah penduduk keseluruhan 40.001, penduduk tersebut 29.598 beragama Islam. Dilihat dari kriteria keluarga sakinah, penduduk dengan katagori pra sakinah 3.598 atau $9 \%$ sehingga jumlah keluarga yang masuk katagori sakinah $91 \%$ meliputi keluarga sakinah I berjumlah 8.880, sakinah II sebanyak 12.670. Sakinah III ada 3.597 dan sakinah plus 853. Kelompok pra sakinah yang menjadi binaan adalah Al- Islah di Kecamatan Sidorejo dan Uswatun Khasanah serta Khoirul Umah di Kecamatan Argomulyo. Dari ketiga kelompok tersebut hanya Uswatun Khasanah yang telah berjalan dan mendapat dana pembinaan dari Kementrian Agama Wilayah Jawa Tengah.

Uswatun Khasanah berada di kecamatan Argomulyo, penduduk Kecamatan Argomulyo pada tahun 2010 secara keseluruhan 42.638 jiwa, terdiri dari penduduk laki-laki 21.278 dan penduduk perempuan 21.360. Dilihat dari segi agama penduduk Argomulyo sebagian besar beragama Islam yakni 33.186 jiwa atau 77,83\%,lainya 22,17 \% penduduk beragama Kristen, Katolik,Hindu dan Budha. Heteroginitas dalam agama ini membentuk corak faham keberagamaan masyarakat dalam memandang agama. Ada komunitas yang memandang agama bukan sesuatu hal yang perlu diperdebatkan karena agama adalah hak bribadi seseorang, sehingga tak menjadi masalah jika dalam satu keluarga terdapat anggota keluarga yang berbeda agama. Pandangan ini tercermin dalam menentukan pasangan hidup yang cenderung melihat dari segi ekonomi dan mengesampingkan agama.

\section{Pola Keluarga}

Masyarakat Argomulyo baik laki-laki maupun perempuan ratarata menikah pada usia diatas 20 tahun keatas. Perkawinan terjadi karena adanya kesepakatan antara seorang laki-laki dan perempuan untuk bersatu membina rumah tangga setelah kedua belah fihak merasa ada kecocokan dan saling mencintai, jarang sekali orangtua menjodohkan anaknya.

Secara umum orang tua yang taat beragama memiliki kriteria dalam menjodohkan anaknya sesuai dengan tuntunan agama, yaitu yang penting seagama soal materi tidak menjadi persyaratan. Mereka memiliki keyakinan bahwa rizki sudah ditentukan Allah, asal mau berusaha keras 
pasti hidupnya akan terjamin dan tenteram. Pada komunitas kaum abangan ada kecenderungan dalam memilih jodoh agama tidak dipermasalahkan, ekonomi maupun rupa menjadi pertimbangan. Pola keluarga dalam komunitas kedua ini memberi kebebasan anggota keluarga dalam memilih pasangan, sehingga dalam satu keluarga terdapat perbedaan agama atau keyakinan.

Tradisi perkawinan secara umum dilakukan sebagaimana proses perkawinan pada masyarakat Jawa. Diawali dari kedatangan pihak laki -laki ke pihak keluarga perempuan untuk melamar.Kunjungan balasan dari pihak perempuan untuk menjawab lamaran dan penentuan hari perkawinan, kemudian pelaksanaan nikah serta resepsi pernikahan. Pihak laki - laki membawa maskawin berupa seperangkat alat salat, uang, pakaian, makanan, dan bahan makanan. Namun proses seperti itu tidak dilaksanakan pasangan hamil pra nikah, perkawinan mereka berlangsung sederhana cukup dilaksanakan di KUA dengan mas kawin seperangkat alat salat. Mereka datang ke KUA untuk menikah dengan wali hakim tanpa didampingi orang tua atau kerabat, cukup didampingi saksi dari kedua belah fihak.

Peristiwa nikah di Kecamatan Argomulyo Pada tahun 2010 tercatat 298 sedangkan perceraian yaitu cerai talak 16 dan gugat cerai 28. Data ini mengindikasikan jumlah gugat cerai lebih dominan, perceraian terjadi disebabkan karena banyak calon pengantin yang hamil sebelum menikah, sehingga perkawinan mereka belum terencana /secara psikologis belum siap sehingga dalam perjalanan rumah tangga sering terjadi perselisihan antar suami isteri.Berdasarkan penuturan salah satu Kepala KUA di Salatiga, $50 \%$ pemohon nikah sudah hamil dan $75 \%$ sudah melakukan hubungan layaknya suami istri.

Permasalahan yang terjadi dalam masyarakat tersebut akibat pergaulan bebas, kurang pengawasan dari orang tua, dan minimnya pengetahuan agama. Kurangnya pemahaman terhadap hukum agama dapat dilihat dari kehadiran pasangan yang hendak menikah ( beda agama) yang menghendaki nikah di KUA dan pelaksanaan akad nikah dengan saksi yang ditunjuk ternyata beda agama. 


\section{Pola Pembinan Keluarga Sakinah}

Tujuan umum program pembinaan gerakan keluarga sakinah adalah sebagai upaya peningkatan kualitas sumber daya manusia secara terpadu antara masyarakat dan pemerintah dalam mempercepat mengatasi krisis yang melanda Bangsa Indonesia untuk mewujudkan masyarakat madani yang bermoral tinggi, penuh keimanan dan akhlak mulia. Sedangkan tujuan khusus pembinaan keluarga sakinah merupakan program yang memadukan antara pembangunan agama, ekonomi, keluarga, pendidikan moral, sosial budaya dan akhlak mulia bangsa yang didukung secara lintas sektoral oleh Departemen Dalam Negeri, Departemen kesehatan, Pemerintah Daerah, serta LSM Agama dan sektor terkait lainnya.( Kementrian Agama RI, 2005, 11-12).

Salah satu tugas KUA dalam pembinaan keluarga sakinah adalah memberikan penasehatan kepada calon pengantin pada waktu pemeriksaan selama 15 menit. Kepala KUA Argomulyo mengatakan bahwa,kalau pada waktu pemeriksaan kedua calon pengantin berhalangan hadir, penasehatan perkawinan dilakukan sewaktu pelaksanaan akad nikah melaluhi khubat nikah. Khutbah nikah disampaikan dengan bahasa Jawa dengan tujuan agar mudah dipahami. Pembinaan pada waktu akad nikah kurang efektif karena berlangsung sangat singkat dan kadang suasananya kurang mendukung. Khutbah nikah kadang juga disampaikan dengan bahasa arab sehingga tidak bisa dipahami, apalagi jika dalam waktu bersamaan banyak terjadi pernikahan sehingga penghulu harus membagi waktu.

Pembinaan usia pranikah maupun pembinaan calon Pengantin dengan metode kursus catin pengantin (suscatin) dilaksanakan maksimal setahun dua kali oleh Kementrian Agama Kota Salatiga. Pembinaan ini belum efektif, karena kegiatan tersebut tidak bisa menjangkau seluruh calon pengantin. Disisi lain dari calon pengantin sendiri kadang tidak punya kesempatan karena tidak bisa meninggalkan pekerjaan atau berada di luar kota. Oleh karena itu perlu adanya komunikasi dan kerjasama dengan tokoh agama tempat calon pengantin berdomisili untuk memberikan pembinaan dan bimbingan secara langsung, sesuai dengan situasi dan kondisi yang memungkinkan adanya pertemuan kedua belah pihak. 
Meskipun KUA menyediakan ruang untuk pelayanan konseling keluarga, pada umumnya masyarakat yang datang berkonsultasi belum mengetahui persyaratan untuk pencatatan perkawinan, terutama pasangan yang akan menikah berbeda agama. Dewasa ini banyak terjadi perkawinan dari latar belakang agama yang berbeda sehingga jumlah mualaf di Salatiga mengalami kenaikan.

Menyikapi permasalahan dalam masyarakat penyuluh agama KUA selaku aparat yang bertugas melakukan dan mengembangkan kegiatan bimbingan atau pembangunan melalui bahasa agama terjun langsung membina masyarakat.Penyuluh melakukan pembinaan keagamaan dan pemberdayaan ekonomi umat melalui majelis taklim. Salah satunya pembinaan keluarga sakinah Uswatun Khasanah di dusun Pamot yang sudah berjalan dan kelompok keluarga Khoirul Ummat yang baru dalam perintisan.

Para pembina keluarga sakinah di lapangan, belum menerapkan kriteria keluarga sakinah yang ditetapkan Kementrian Agama. Para penyuluh merasa kesulitan menerapkan kriteria tersebut pada masyarakat binaan. Untuk mengukur kriteria keluarga sakinah ada yang menyampaikan dengan mengacu pada kriteria keluarga sejahtera berdasarkan data di kelurahan dan ada yang mengklasifikasikan keluarga sakinah dengan kriteri Kementrian Agama tetapi disesuaikan dengan kondisi masyarakat setempat, seperti melihat keaktifan salat berjamaah. Untuk mengetahui prilaku keagamaan masyarakat penyuluh menanyakan langsung kepada tokoh agama setempat yang berinteraksi setiap hari dengan para jamaah. Pembinaan keluarga sakinah belum terprogram, pembina keluarga sakinah menyatakan bahwa pembinaan yang dilakukan melihat situasi dan kondisi masyarakat tanpa ada perencanaan.

Pembinaan umat yang dilakukan penyuluh maupun para tokoh agama tidak secara khusus mengupas tentang keluarga sakinah. Materi pembinaan bersifat umum, menyangkut seluruh aspek kehidupan, karena masyarakat masih dalam masa transisi proses menjadi keluarga sakinah dan perlu pendekatan kekeluargaan.Penyuluh memberikan motivasi dengan berbagai cara yang dapat menarik masyarakat untuk mengikuti majelis taklim ataupun kegiatan keagamaan lainya. Oerientasi sebagian masyarakat pada masalah ekonomi, ada ungkapan melu ngaji ra intuk 
duwit artinya pengajian tidak menghasilkan uang. Kondisi ini mendorong penyuluh untuk merintis pengajian dan melakukan pemberdayaan ekonomi dalam majelis taklim. Bentuk kegiatan ceramah agama dan melakukan ketrampilan dengan membuat kue. Penyuluh juga besedia untuk membantu memasarkan makanan yang diproduksi masyarakat.

Pembinaan keluarga sakinah meskipun dalam batas majelis taklim telah dirasakan manfaatnya oleh masyarakat, keikut sertaan dalam kegiatan majelis taklim dan seringnya mendengarkan ceramah agama berengaruh terhadap perubahan perilaku keagamaan masyarakat dibidang ibadah. Secara umum kesadaran masyarakat untuk mewujudkan kehidupan yang agamis nampak pada perhatian orang tua terhadap pendidikan agama anakanak mereka. Kegiatan pengajian semakin semarak dengan diselenggarakan peringatan hari-hari besar seperti peringatan Isro' mi'roj, Nuzulul Qur'an dan Maulid Nabi. Perubahan perilaku ini tidak semata - mata dipengaruhi oleh ceramah agama, kondisi alam dan seringnya terjadi bencana juga berpengaruh menguatkan keimanan masyarakat untuk mendekatkan diri kepada Tuhan.

Keberasilan tersebut bersifat individu yaitu prestasi penyuluh agama, ketekunan dan kedekatan penyuluh agama kepada masyarakat binaan menentukan terbentuknya keluarga sakinah. Dalam pembinaan keluarga sakinah belum merambah usaha peningkatan ekonomi keluarga yang semestinya dapat di bentuk kelompok usaha kecil dengan membangun kerja sama dengan instansi terkait dilingkunagn Pemerintah Daerah Kota Salatiga.

Desa Pamot berdekatan dengan jalan lingkar Salatiuga, dibukanya Jalan Lingkar Selatan (JLS) di kota Salatiga menjadi tantangan baru bagi para petugas KUA, tokoh masyarakat maupun tokoh agama dalam pembinaan generasi muda, karena area disekitar jalan tersebut banyak dimanfaatkan untuk melakukan perbuatan yang dilarang agama. Kendala lain perubahan pola pikir masyarakat yang lebih berorientasi pada masalah ekonomi dan keterbatasan dana pembinaan keluarga sakinah. JLS dapat dimanfaatkan untuk lahan usaha untuk memasarkan hasil ketrampilan masyarakat binaan. 


\section{Realitas Keluarga Sakinah di Masyarakat}

Potret keluarga sakinah dapat dilihat dari tiga katagori bangunan keluarga yaitu keluarga ideal, keluarga cukupan dan keluarga kurang ideal. Kelompok keluarga sakinah Uswatul Khasanah masih pada tataran belum mencapai keluarga yang ideal karena masih dalam proses menuju keluarga sakinah. untuk mencapai keluarga ideal masih membutuhkan waktu yang cukup panjang, tetapi upaya masyarakat untuk meraih itu dapat dilihat dari semangat kegotong royongan warga dalam membangun sarana dan prasrana pembinaan.

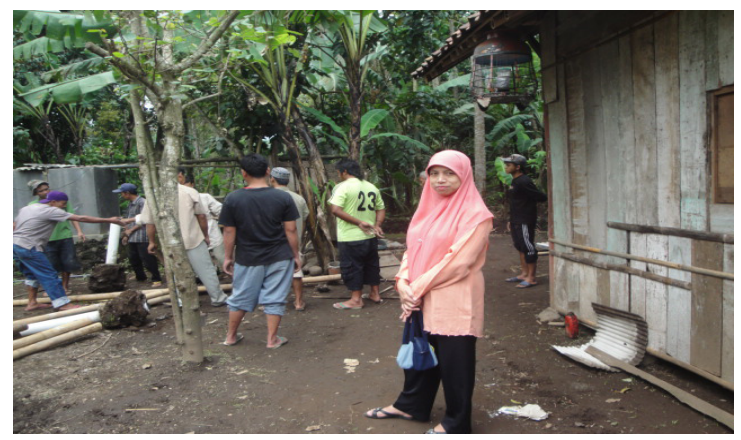

Gambar 1. Kelompok Keluarga Sakinah Uswatul Khasanah Kerja Bakti Membuat Kandang Kambing Dan Gasebo

Sumber : Dokumen Peneliti, Salatiga 2012.

\section{a. Keluarga Ideal}

Konsep keluarga sakinah atau keluarga yang ayem tenteram menurut masyarakat bertitik tolak pada keimanan seseorang dan akhlaknya, bukan dari segi materi yang dimiliki. Keluarga sakinah tidak hanya terbatas pada keluarga inti, tetapi meliputi keluarga luas/ kerabat dan para tetangga. Konsep ini menegaskan bahwa lingkungan berpengaruh terhadap pembentukan keluarga sakinah.Kondisi lingkungan yang agamis berpotensi untuk membentuk keluarga sakinah, tetapi kesakinahan tersebut tidak bisa terlepas dari etos kerja masyarakat,karena dengan kerja keras kondisi ekonomi seseorang akan menguat paling tidak hidup mapan,tercukupi kebutuhannya.Ukuran kemapanan dalam konsep keluarga sakinah kembali kepada masing-masing individu dan bagaimana sikapnya dalam menghadapi keadaan. 
Menurut masyarakat keluarga ideal adalah keluarga yang bisa tercukupi kebutuhan material dan spiritual. Berpendidikan, memiliki penghasilan tetap, suami istri bekerja sama untuk mencapai cita-cita, berhasil mendidik anak dengan baik, terjalin hubungan yang harmonis dalam keluarga, konflik yang terjadi bersifat positif, aktif dalam kegiatan sosial keagamaan dan bisa menjadi tauladan dalam masyarakat.

Secara umum masyarakat perpandangan persyaratan keluarga ideal diawali dari proses pemilihan jodoh dengan melihat latar belakang keluarga, agama, perilaku, kondisi ekonomi kecukupan, bisa membahagiakan keluarga dan rupa juga menjadi pertimbangan. Agama yang paling utama, masalah ekonomi yang penting ada kemauan untuk kerja keras, karena derajad dan pangkat tidak menjamin ketentraman dalam rumah tangga.

Hasil dari Fucus Group Discussion ( FGD), beberapa pendapat yang disampaikan peserta dapat dirumuskan bahwa keluarga ideal dari segi agama tidak selalu berasal dari latar belakang perkawinan masyarakat yang tergolong santri dengan santri, tetapi bisa terbentuk dari masyarakat yang terkolong santri dengan abangan, abangan dengan abangan, maupun abangan dengan santri. Bila mengacu ukuran keluarga sakinah yang ditetapkan Kementrian Agama yang lebih menekankan aspek spiritual atau mengukur tingkat keimanan, sementara tingkat keimanan masyarakat diakui mengalami pasang surut maka label kesakinahan juga akan mengalami pergeseran.

\section{b. Keluarga cukupan}

Keluarga cukupan, keluarga yang telah tercukupi kebutuhan spritual maupun material tetapi masih terbatas, atau pas-pasan dan tidak punya tabungan. keluarga yang sedang masih terjadi percekcokakan, Kedekatan ibu, ayah dan anak wajar dan ada kerjasama dalam rumah tangga.

Kecukupan dalam masalah ekonomi adalah relatif, meski dalam keadaan kekurangan atau keterbatasan, kalau bisa menerima dengan ikhlas akan merasa cukup dan puas dengan apa yang dimiliki. Seperti berbagai pandangan dari warga kelompok Uswatun Khasanah, mereka sependapat bahwa keluarga yang ayem tentrem atau sakinah,syaratnya saling keterbukaan antara suami istri walau kebutuhan banyak dan penghasilan kurang tetapi bisa cukup, kuncinya adalah ihtiar dan menerima apa adanya. 
Cukup atau kedudukan ditengah, diantara dua hal yang bertentangan bagi orang jawa adalah yang dianggap ideal. Hal ini bagi orang jawa merupakan perwujudan sebuah nilai yang dianggap paling penting : sak madya. Artinya yang sedang-sedang saja, sak cukupe, tengahtengah, kalau kaya tidak usah kaya sekali tapi juga tidak melarat sekali, urip sak madya hidup sedang-sedang saja dianggap ideal (Handayani dan Novianto, 2004,

Bangunan keluarga yang terdiri dari abangan dan santri atau sebaliknya atau abangan dengan abangan dan bisa mewujudkan keluarga yang teteram saling mengasihi dan hidup sejahtera dalam kenyatannya dapat digolongkan pada keluarga cukupan, demikian pula keluarga yang dibangun antara santri dengan santri, kalau dalam perjalanan mereka masih sering terjadi perselisihan atau tidak aktif dalam kegiatan keagamaan dan kemsyarakatan.

\section{c. Keluarga Kurang Ideal}

Keluarga yang kurang ideal, menurut masyarakat keluarga yang terbentuk dari perkawinan yang tidak sah, belum terpenuhi kebutuhan spiritual maupun metrialnya. Belum menjalankan ibadah secara rutin dan pengetahuan agamanya rendah. Kondisi ekonomi terbatas, suami maupun istri kurang bertanggung jawab terhadap keluarga,tidak saling terbuka sehingga sering terjadi pertengkaran.

Kasus perkawinan yang terjadi antara laki-laki abangan dan perempuan abangan bisa sakinah sedikit jumlahnya. Secara umum perkawinan dari awalnya sudah tidak baik, dalam perjalanan keluargapun cenderung tidak baik. Demikian pula perkawinan antara laki-laki abangan dan perempuan santri, pada umumnya juga kurang ideal, meskipun istrinya aktif beribadah tetapi laki-lakinya tidak pernah menjalan agama situasi dalam rumah tangga sulit diliputi suasana keagamaan karena pemimpin dalam keluarga tersebut tidak memberikan contoh yang baik dan tidak menerapkan kehidupan yang Islami, suami pemabuk, suka minum dan main judi. 


\section{Simpulan}

Konsep keluarga sakinah belum banyak dipahami oleh tokoh agama maupun masyarakat. Pembinaan keluarga sakinah yang telah berjalan hanya sebatas pada kelompok yang telah mendapat bantuan dari Kementrian Agama Wilayah Jawa Tengah dalam lingkup kecil dan ide dari penyuluh Agama. KUA yang memiliki wewenang dan melakukan tugas pembinaan belum tergerak untuk menyusun program pembinaan keluarga sakinah dan melakukan pengembangan terhadap daerah binaan yang telah ada.

Pembinaan keluarga sakinah masih terbatas pada penasehatan pra nikah dan konseling keluarga dalam bentuk pelayanan bagi yang memerlukan (datang ke KUA) serta melalui majelis taklim.Kursus calon pengantin ( Suscatin) belum efektif karena tidak menjangkau masyarakat luas. Konsep keluarga sakinah berdasarkan kriteria Kementrian Agama kesulitan meterapkan,kurang pas jika ukuran yang dipakai kriteria keluarga sejahtera. Pembinaan keluarga sakinah masih bersifat umum dalam bentuk majlis taklim. Pendampingan ekonomi dalam bentuk palatihan dan ketrampilan masih belum banyak dilakukan, kegitan masih terbatas pada pinjaman bergulir.

Secara umum masyarakat menginginkan terwujudnya keluarga yang tentrem ayem dalam bahasa agama keluarga sakinah.Keluarga yang diidealkan masyarakat adalah keluarga yang beriman dan terpenuhi kebutuhan materiil. Meskipun tidak punya harta yang berlebih tetapi tetap iman itu sudah cukup. Jangan sampai tidak punya keduanya itu keluarga yang tidak ideal.

Berdasarkan temuan - temuan dalam penelitian disarankan kepada Kementrian Agama terkait dengan program pembinaan keluarga sakinah sebagai berikut :

1. Program Pembinaan keluarga sakinah perlu ditata ulang dengan mempertimbangkan aspek spiritual maupun matrerial. Masyarakat perlu dibekali ketrampilan dan dilakukan pendampingan. Perlu alokasi dana untuk pengembangan keluarga sakinah secara merata. 
2. Konsep maupun kriteria keluarga sakinah perlu dipertegas, sehingga tidak salah tafsir dan disesuaikan dengan kondisi masyarakat.

3. Perlu dibangun kerja sama dengan instansi lain yang terkait seperti Dinas Sosial dan Tranmigrasi,Bapermas,Tokoh masyarakat dan tokoh agama untuk keberhasilan pembinaan keluarga sakinah. 


\section{BIBLIOGRAFI}

Departemen Agama RI, 2005,Buku Petunjuk Teknis pembinaan keluarga Sakinah, Jakarta, Ditjen Bimas Islam dan Penyelenggaraan Haji, Departemen Agama RI, 2002,Modul Pembinaan Keluarga Sakinah, Jakarta: Ditjen Bimas Islam dan Penyelenggaraan Haji.

Departemen Agama RI, 2002,Modul Pendidikan Agama dalam Keluarga, Jakarta: Ditjen Bimas Islam dan Penyelenggaraan Haji.

Departemen Agama RI, 2006,Pandangan Masyarakat terhadap Keluarga Sakinah, Jakarta: Pusat Penelitian dan Pengembangan Agama.

Direktorat Pembinaan Badan Peradilan Agama Direktorat Jendaeral Pembinaan Kelembagaan Agama Islam Departemen Agama, 1991/1992.Kompilasi Hukum Islam Di Indonesia, Jakarta.

Euis Sunarti, MS. 2006, Indikator Keluarga Sejahtera; Sejarah Pengembangna, Evaluasi, Dan Keberlanjutan, Bogor, Fakultas Ekologi Manusia Institut Pertanian Bogor.

Handayani dan Ardhian Novianto,2004, Kuasa Wanita Jawa,Yogyakarta LkiS.Pelangi Aksara.

Kementrian Agama RI ,Ditjen Bimas Islam dan penyelenggaraan haji Direktorat Urusan Agama Islam, Jakarta, 2005, Petunjuk Teknis Pembinaan Gerakan Keluarga Sakinah

Kantor Wilayah Kementrian Agama Jawa Tengah, Badan Penasehatan Pembinaan dan Pelestarian Perkawinan, (BP4), 2007, Buku Panduan Keluarga Muslaim,Semarang.

Moleong, Lexy J., 1995 Metodologi Penelitian Kualitatif, Bandung: Rosda Karya

Ratna Susi Rahmawati, Analisis Perencanaan Pembinaan Keluarga Sakinah oleh Skripsi,BP4 KUA Gondokusuman Yogyakarta, Yogyakarta: UIN Sunan Kalijaga, 2010

Su’adah, 2005, Sosiologi Keluarga, Malang, UMM Press. 
Ulfatmi, 2011, Keluarga Sakinah Dalam Perspektif Islam,(Studi Terhadap Pasangan Yang Berhasil Mempertahankan Keutuhan Perkawinan di Kota Padang),Jakarta, Kementrian Agama RI.

Zaini Muchtarom, 1988, Santri dan Abangan Di Jawa, jilid II,Jakarta, INIS. 
